\title{
A retrospective study on the association between different lengths of the dry period and subclinical mastitis, milk yield, reproductive performance, and culling in Chilean dairy cows
}

\author{
P. Pinedo, ${ }^{*}$ C. Risco,${ }^{* 1}$ and P. Melendez ${ }^{*} \dagger$ \\ *College of Veterinary Medicine, University of Florida, Gainesville 32610-0136 \\ †Facultad de Medicina Veterinaria, Universidad Santo Tomas, Viña del Mar, Chile
}

\begin{abstract}
The objective of this study was to determine the association between different dry period lengths and somatic cell counts, milk yield, reproductive performance, and risk of early culling during the subsequent lactation of Chilean dairy cows. The length of the dry period was classified into 5 categories: 0 to $30 \mathrm{~d}, 31$ to $52 \mathrm{~d}, 53$ to $76 \mathrm{~d}, 77$ to $142 \mathrm{~d}$, and 143 to $250 \mathrm{~d}$. Generalized mixed models were used and included herd as random effect. Time-to-event analyses were performed for evaluation of reproductive performance and culling risk. The odds of subclinical mastitis ( $\log$ linear score, LNSCC $\geq 4.5$ ) during early lactation increased with extended dry periods (143 to $250 \mathrm{~d}$ ) during first, second, and third test day compared with the reference dry period of 53 to $76 \mathrm{~d}$ [odds ratio $(\mathrm{OR})=1.27,1.16$, and 1.31 , respectively]. Short (0 to $30 \mathrm{~d}$ ) and extended dry periods had a detrimental effect on early lactation and 305-d milk yield compared with the reference dry period. Longer dry periods were associated with increased number of days for calving-to-first service interval and calving to conception interval. Average calving-to-first service interval for short and extended dry period were $83 \mathrm{~d}$ and $89.4 \mathrm{~d}$, respectively. Average days to conception were $127.8 \mathrm{~d}$ and $131.4 \mathrm{~d}$ for a dry period of 31 to $52 \mathrm{~d}$ and extended dry period, respectively. Similarly, the number of services per conception increased with length of previous dry period from 1.62 (31 to 52 d) to 2.44 (143 to $250 \mathrm{~d}$ ). Cows with previous short and extended dry period had higher odds of culling when compared with cows in the reference group $(\mathrm{OR}=2.20$ and 1.57, respectively). Compared with the reference group, cows in the dry period category 77 to $142 \mathrm{~d}$ had the highest odds of death followed by the category 143 to $250 \mathrm{~d}$ ( $\mathrm{OR}=1.27$ and 1.18 , respectively). When death and live culling were combined, the highest odds of combined death and culling were for cows in the cat-
\end{abstract}

Received February 5, 2010.

Accepted October 3, 2010.

${ }^{1}$ Corresponding author: riscoc@ufl.edu egories 0 to $30 \mathrm{~d}$ and 143 to $250 \mathrm{~d}(\mathrm{OR}=1.63$ and 1.44, respectively). We conclude that extended dry periods (143 to $250 \mathrm{~d}$ ) increase the odds of subclinical mastitis occurrence during early lactation and have a negative association with reproductive performance. Short and extended dry periods were negatively associated with early lactation and 305-d milk yield and were related to increased overall culling when compared with the reference dry period.

Key words: dry period, culling, reproduction, subclinical mastitis

\section{INTRODUCTION}

A nonlactating or dry period for pregnant dairy cows is recommended between consecutive lactations based on the nutritional needs of the late pregnant cow and to allow proper involution of the mammary gland epithelium to maximize milk yield during the subsequent lactation (Swanson, 1965; Hurley, 1989; Annen et al., 2004; Church et al., 2008). The dry period also permits extended intramammary antibiotic therapy to reduce the prevalence of existing infections and reduce the incidence of new infections, without the risk for violative milk residues (Eberhart, 1986).

The optimal duration of the dry period has been a subject of debate, with a period of 51 to $60 \mathrm{~d}$ given as the conventional recommended length (Bachman and Schairer, 2003; Church et al., 2008). However, because of management decisions related to gestation length and milk yield, it is common on many farms for cows to have involuntary long or short dry periods. On the other hand, in recent years, consideration has been given to a shorter, 30-d dry periods. Arguments for a 30-d dry period include additional income from milk yield at the end of lactation and improved nutritional state to meet the physiological challenges of the transition period (Bachman and Schairer, 2003; Gulay et al., 2003).

As reviewed by Bachman and Schairer (2003), when dry periods were reduced from 60 to $30 \mathrm{~d}$, the change in milk production ranged from a $10 \%$ decrease to a $1 \%$ increase. However, after controlling for milk yield, short 
dry periods resulted in lower fertility (14 more days open for 0-10 d dry vs. 61-65 d dry). Similarly, short dry periods were associated with higher SCS during the subsequent lactation (Kuhn et al., 2006a). Conversely, a shortened (34 d) dry period improved the reproductive performance of third-lactation or greater cows compared with the traditional dry period length (20.3 vs. $10.6 \%$ of pregnancy at 70 DIM for $34 \mathrm{~d}$ and $43 \mathrm{~d}$ dry, respectively; Watters et al., 2009). Rastani et al. (2005) reported that shortening the dry period improved the energy balance and decreased the mobilization of body reserves after calving. Still, a clear effect for variations of dry period length on health has not been described (Bachman and Schairer, 2003; Watters et al., 2008), and most studies have centered on the consequences of shortened dry periods (Grummer and Rastani, 2004).

The decision of when to dry off a lactating dairy cow is based on milk production, gestation length, and replacement costs. The effect of dry period lengths varying from less than 30 to $80 \mathrm{~d}$ has been reported (Bachman and Schairer, 2003), but limited information exists about the overall consequences of diverse lengths of dry period on performance, udder health, and culling in large populations. In the studies cited earlier (Gulay et al., 2003; Watters et al., 2008, 2009), cows that received a short dry period were fed a balanced diet that met the required nutritional needs of prepartum transition cows ( -3 wk from calving). Similarly, cows that were assigned to a long dry period were fed a diet that met the nutritional requirements for dry cows. However, little information exists on the effect of involuntary variations in days dry that could occur because of different stages of gestation at dry off, resulting in failure to meet nutritional requirements during the dry period.

We hypothesized that different durations of dry period length were associated with udder health status, milk yield, reproduction, and culling during the following lactation. Therefore, the objective of the present study was to retrospectively determine the association between dry period length and SCC, milk yield, reproductive performance, and early culling during the subsequent lactation in a population of Chilean dairy cows.

\section{MATERIALS AND METHODS}

\section{Dairy Farms and Management}

This was a retrospective cohort study that considered dairy farms from the south-central area of Chile. The area is between $36^{\circ} 00^{\prime}$ and $38^{\circ} 30^{\prime} \mathrm{S}$ and between $71^{\circ} 00^{\prime}$ $\mathrm{W}$ and the Pacific Ocean. Climate is temperate with winter rainfall $(1,380 \mathrm{~mm} / \mathrm{yr})$ and temperatures that range from $0^{\circ} \mathrm{C}$ in winter to $32^{\circ} \mathrm{C}$ in summer (Instituto Geografico Militar, 2006). The south-central area of Chile is a typical agricultural region, and has $30 \%$ of Chile's total cattle population.

Dairy farms included in this study consisted of Holstein cattle $(90 \%)$ and crossbred Black-Pied $\times$ Holstein (10\%). Median and interquartile range bounds for average milk yield (305-d) per herd were 7,249, 6,154, and, $8,277 \mathrm{~kg} /$ cow, respectively. Herd size ranged from 37 to 800 cows, with median and interquartile range bounds of 177, 115, and 301 cows, respectively. Housing was drylot $(40 \%)$, freestalls $(40 \%)$, grazing $(10 \%)$, and mixed systems (10\%). Feeding systems were TMRbased and comprised corn silage, alfalfa hay, and concentrates (50\%), top-dressed concentrate, corn silage, and green chop/hay alfalfa (30\%), grazing (10\%), and mixed systems $(10 \%)$. Dry cow diets were formulated to meet or exceed the nutrient requirements established by NRC (2001). In general, the diets included a faroff period based on corn silage, gramineae hay, and minerals, and a close-up period ( $21 \mathrm{~d}$ before due date) diet of corn silage, ryegrass, soybean meal, and corn grain. Reproductive management consisted of AI based on estrus detection that included visual inspection for primary signs of estrus at least twice per day (80\%), natural service $(10 \%)$, and mixed AI and natural service systems (10\%). In natural service herds, when a cow was found to be in estrus, she was brought to the bull for breeding; therefore, the date of breeding was known. No estrus- or ovulation-synchronization protocols were used in this population during the period analyzed. Crude averages for calving interval, calving-to-firstservice interval (CFSI), calving-to-conception interval (CCI), and services per conception (SC) during the period in analysis were $407 \mathrm{~d}, 87 \mathrm{~d}, 128 \mathrm{~d}$, and 1.74 services, respectively.

Time for dry off varied among farms, but days to next calving ( $60 \mathrm{~d}$ to due date) and milk yield were the most commonly used criteria. Milking frequency was $3(35 \%)$ or 2 times daily $(65 \%)$ using standard, commercial automated milking machines. Average annual culling rate per herd was $29 \%$.

\section{Study Design}

This retrospective cohort study analyzed data collected by a government-certified recording system organization (Insecabio Ltda., Los Angeles, Chile) that has monitored (monthly) a population of approximately 12,000 Holstein cattle in 239 herds during the last $17 \mathrm{yr}$. The study used records from a population of 223 farms, comprising 145,984 lactations between 1997 and 2009. Given that the enrollment in this recording system is voluntary and involves a cost, not all of the farms in 
the study population were represented during the entire period under analysis. Consequently, this population includes the total of herds entering and leaving the system for this period of time. Data were obtained by certified technicians during monthly visits to the farms. Technicians recorded individual milk production during a complete-day milking cycle (2 or 3 times/d milking), and collected individual milk samples from every cow during the milking. Samples were preserved by addition of potassium dichromate and analyzed in a Combifoss 5000 (Foss, Hillerød, Denmark) device comprising a Fossomatic 5000 somatic cell counter (based on the flow cytometry principle) and a Milko-Scan 4000 component for MUN, fat, and protein analysis.

Information collected on the farm consisted of the herd-unique code identification, test day date, number of milking cows and distribution per number of lactation, and average milk production of the herd on the day of sampling. Cow individual information consisted of test-day milk during the technician visit, milk components (SCC, MUN, fat, and protein), and reproductive and management events such as calving date, breeding date and number, pregnancy diagnosis, abortion, date of dry off, culling date, and death date, among others.

\section{Outcome Variables}

The occurrence of subclinical mastitis was analyzed using the first 3 monthly test-day SCC (up to 100 DIM). Counts were natural log-transformed to a log linear score (LNSCC) and categorized as low $(<4.5)$ and high $(\geq 4.5)$. High LNSCC were considered an indication of subclinical mastitis (Moore et al., 2005). The occurrence of a high LNSCC in each of the test days was analyzed separately. Clinical mastitis cases were excluded from the analysis. Milk yield was evaluated considering the first 3 monthly test-day milk yields after calving (up to 100 DIM) and milk production standardized to 305-d based on an approved methodology (Keown et al., 1986). Relative monthly test-day milk yields were estimated as deviations from the corresponding test-day milk yield average from cows calving in the same herd-year-season.

Reproductive performance was evaluated by the following outcome variables: (1) CFSI, defined as the number of days between parturition and the subsequent first breeding, (2) CCI, defined as the number of days between parturition and the breeding that resulted in pregnancy, (3) SC, defined as the number of breedings that a cow required to conceive, and (4) conception at first service (CFS), defined as the result of the first breeding after calving (pregnancy or not).

Two categories were considered for culling: cows that died and cows that were culled within $100 \mathrm{~d}$ after calv- ing. The analysis considered these 2 categories separately and combined.

\section{Explanatory Variables and Statistical Analysis}

First lactations and lactations that started with an abortion were excluded from the analysis. The distribution of the continuous variables was examined through the use of histograms and descriptive statistics (e.g., means, medians, and standard deviations) to assist in the subsequent categorization of the explanatory variables. Continuous explanatory variables were categorized by use of percentiles to facilitate the analysis and interpretation.

The main explanatory variable was length of the dry period, categorized in 5 periods: 0 to $30 \mathrm{~d}, 31$ to 52 d, 53 to $76 \mathrm{~d}, 77$ to $142 \mathrm{~d}$, and 143 to $250 \mathrm{~d}$ (0-10, 11-25, 26-75, 76-90, and 91-100 percentiles, respectively). This categorization resulted in 5.7, 21.3, 48.2, 19.5 , and $5.3 \%$ of the records in each category (from short to extended dry period). The period 53 to $76 \mathrm{~d}$ was considered as the reference category in the logistic regression and time-to-event analyses. Explanatory variables considered in the analysis for the purpose of controlling for potential confounding included parity (2, 3 , and $\geq 4$ ), calving season (summer $=$ December 1 to February 28/29; autumn = March 1 to May 31; winter $=$ June 1 to August 31; and spring = September 1 to November 30), year of calving (1997 to 2006), herd size, and relative cow and herd 305-d milk yield. Herd size was categorized by number of cows as $\leq$ lower quartile $(<115$ cows); between lower and higher quartiles (115 to 301 cows); and $\geq$ higher quartile (>301 cows).

Cow and herd 305-d milk yield were expressed as relative values deviated from the year-season mean and categorized as $\leq$ lower quartile; between lower and higher quartiles; and $\geq$ higher quartile. Cow relative 305-d milk yield was calculated as the difference from the herd mates' average milk yield: $<-817 \mathrm{~kg}$ (low), -817 to $786 \mathrm{~kg}$ (intermediate), and $>786 \mathrm{~kg}$ (high). Herd-relative 305-d milk yield was calculated as the difference from the herd milk yield average and the year-season average: $<-1.308 \mathrm{~kg}$ (low), $-1,308$ to 1,744 $\mathrm{kg}$ (intermediate), and $>1.744 \mathrm{~kg}$ (high). Milk yield standardized to 305 -d was defined as low $=<6,029$ $\mathrm{kg}$; medium $=6,030$ to 8,840 ; and high $=>8,040$. The corresponding test-day milk yield was included as a covariate when the probability of subclinical mastitis was analyzed. Relevant 2-way interactions were included in preliminary models, but they were removed when not significant.

Models for subclinical mastitis (LNSCC $\geq 4.5$ ), CFS, and culling were evaluated by logistic regression (PROC GLIMMIX; SAS Inst. Inc., Cary, NC), through 
Table 1. Descriptive statistics for length of dry period and explanatory variables

\begin{tabular}{lcccc}
\hline Variable & Mean & SD & Median & $\begin{array}{c}\text { Interquartile } \\
\text { range }\end{array}$ \\
\hline Dry period, d & 69.4 & 35.7 & 61.0 & $51-76$ \\
First test-day milk yield, kg & 30.7 & 9.2 & 30.2 & $24.4-36.6$ \\
Second test-day milk yield, kg & 32.8 & 9.9 & 32.4 & $26-39.4$ \\
Third test-day milk yield, kg & 31.4 & 9.8 & 31.0 & $24.4-38$ \\
Cow 305-d milk yield, kg & 7,881 & 2,086 & 7,676 & $6,317-9,216$ \\
Herd 305-d milk yield, kg & 7,503 & 1,567 & 7,249 & $6,154-8,277$ \\
\hline
\end{tabular}

a backward elimination procedure with the significance level for inclusion in the final models set at $\alpha \leq 0.10$. The model fit was evaluated by comparison of the difference in the deviances by the likelihood ratio test. Relative test-day milk yields, 305-d milk yield, CFSI, CCI, and SC were evaluated using the identity link function (PROC GLIMMIX; SAS Inst. Inc., Cary, NC). The models included herd as the random effect, with the interest (dry period length) and control variables (potential confounding variables) considered as fixed effects. Time-to-event analyses were performed for CFSI, CCI, and culling using Kaplan-Meier survival curves (PROC LIFETEST) and the Cox's proportional hazards regression model (PROC PHREG; SAS Inst. Inc., Cary, NC).

\section{RESULTS AND DISCUSSION}

After edits, 90,286 second or greater lactations in 223 herds were available for the analysis. Descriptive statistics for dry period length and other variables analyzed are shown in Table 1.

\section{Subclinical Mastitis}

The odds of subclinical mastitis (LNSCC $\geq 4.5$ ) occurrence during early lactation increased with extended dry periods. After adjusting for parity, test-day milk yield, relative cow and herd 305-d milk yield, calving season-year, and herd size, the odds of subclinical mastitis during first, second, and third test-day for cows with an extended dry period (143 to $250 \mathrm{~d}$ ) were 1.27 , 1.16 , and 1.31 times the odds of subclinical mastitis for cows in the reference dry period (53 to $76 \mathrm{~d}$ ). The association of short dry period (0 to $30 \mathrm{~d}$ ) with subclinical mastitis occurrence was only significant on the second test-day. The odds of subclinical mastitis for cows in this category were 0.87 [odds ratio $(\mathbf{O R}) ; 95 \% \mathrm{CI}=$ 0.78 to 0.97$)$ times the odds of subclinical mastitis for cows in the reference category (53 to $76 \mathrm{~d}$; Table 2 ).

In partial agreement with the results of the current study, cows with dry periods of $\leq 30 \mathrm{~d}$ were reported to have a lower number of new intramammary infections than cows with longer dry periods (Natzke et al., 1975). Although the difference was not significant, a tendency

Table 2. Odds ratios for occurrence of subclinical mastitis (LNSCC $\geq 4.5$ ) during the first 3 test-days by categories of length of the dry period (reference dry period $=56$ to $76 \mathrm{~d})^{1}$

\begin{tabular}{|c|c|c|c|c|}
\hline Dry period category & $\begin{array}{c}\%(\mathrm{n}) \\
\text { affected }\end{array}$ & $\begin{array}{l}\text { Odds } \\
\text { ratio }\end{array}$ & $\begin{array}{l}95 \% \\
\mathrm{CI}^{2}\end{array}$ & $P$-value \\
\hline \multicolumn{5}{|c|}{ LNSCC $\geq 4.5$ (first test-day) } \\
\hline 0 to $30 \overline{\mathrm{d}}$ & $29(1,172)$ & 1.03 & $0.91-1.16$ & 0.40 \\
\hline 31 to $52 \mathrm{~d}$ & $26(5,206)$ & 1.02 & $1.00-1.06$ & 0.75 \\
\hline 53 to $76 \mathrm{~d}$ & $26(10,880)$ & 1 & - & - \\
\hline 77 to $142 \mathrm{~d}$ & $26(4,950)$ & 0.99 & $0.93-1.05$ & 0.97 \\
\hline 143 to $250 \mathrm{~d}$ & $35(1,506)$ & 1.27 & $1.20-1.40$ & 0.001 \\
\hline \multicolumn{5}{|c|}{ LNSCC $\geq 4.5$ (second test-day) } \\
\hline 0 to $30 \overline{\mathrm{d}}$ & $26(1,153)$ & 0.87 & $0.78-0.97$ & 0.01 \\
\hline 31 to $52 \mathrm{~d}$ & $27(5,147)$ & 0.98 & $0.93-1.03$ & 0.59 \\
\hline 53 to $76 \mathrm{~d}$ & $27(11,717)$ & 1 & - & - \\
\hline 77 to $142 \mathrm{~d}$ & $31(5,368)$ & 1.05 & $1.00-1.10$ & 0.16 \\
\hline 143 to $250 \mathrm{~d}$ & $34(1,498)$ & 1.16 & $1.10-1.27$ & 0.0002 \\
\hline \multicolumn{5}{|c|}{ LNSCC $\geq 4.5$ (third test-day) } \\
\hline 0 to $30 \overline{\mathrm{d}}$ & $28(1,236)$ & 0.94 & $0.86-1.04$ & 0.09 \\
\hline 31 to $52 \mathrm{~d}$ & $28(5,446)$ & 1.00 & $0.96-1.05$ & 0.66 \\
\hline 53 to $76 \mathrm{~d}$ & $28(12.309)$ & 1 & - & - \\
\hline 77 to $142 \mathrm{~d}$ & $33(5,741)$ & 1.05 & $1.00-1.10$ & 0.054 \\
\hline 143 to $250 \mathrm{~d}$ & $38(1,726)$ & 1.31 & $1.19-1.42$ & 0.001 \\
\hline
\end{tabular}

${ }^{1}$ Significant covariates $(P \leq 0.05)$ in the final models included parity, test-day milk yield, relative cow, and herd $305-\mathrm{d}$ milk yield, and calving season-year. Herd was included as random effect in the analysis.

${ }^{2} 95 \%$ CI for the odds ratio. 
Table 3. Least squares means for relative test-day milk yield and cow 305-d milk yield for different categories of length of the dry period ${ }^{1}$

\begin{tabular}{|c|c|c|c|c|}
\hline Dry period category & LSM & SEM & $95 \% \mathrm{CI}$ & $P$-value ${ }^{2}$ \\
\hline \multicolumn{5}{|c|}{ Relative test-day milk yield ${ }^{3} \mathrm{~kg}$ (first test-day) } \\
\hline 0 to $30 \mathrm{~d}$ & $-0.39^{\mathrm{a}}$ & 0.123 & $-0.63-0.15$ & 0.001 \\
\hline 31 to $52 \mathrm{~d}$ & $0.75^{\mathrm{c}}$ & 0.072 & $0.60-0.89$ & $<0.001$ \\
\hline 53 to $76 \mathrm{~d}$ & $1.30^{\mathrm{d}}$ & 0.063 & $1.17-1.42$ & $<0.001$ \\
\hline 77 to $142 \mathrm{~d}$ & $0.76^{\mathrm{c}}$ & 0.076 & $0.61-0.91$ & $<0.0001$ \\
\hline 143 to $250 \mathrm{~d}$ & $0.20^{\mathrm{b}}$ & 0.119 & $-0.03-0.44$ & 0.092 \\
\hline \multicolumn{5}{|c|}{ Relative test-day milk yield, ${ }^{3} \mathrm{~kg}$ (second test-day) } \\
\hline 0 to $30 \mathrm{~d}$ & $-0.18^{\mathrm{a}}$ & 0.101 & $-0.38-0.01$ & 0.07 \\
\hline 31 to $52 \mathrm{~d}$ & $0.83^{\mathrm{c}}$ & 0.060 & $0.70-0.94$ & $<0.0001$ \\
\hline 53 to $76 \mathrm{~d}$ & $1.22^{\mathrm{e}}$ & 0.051 & $1.12-1.32$ & $<0.0001$ \\
\hline 77 to $142 \mathrm{~d}$ & $1.02^{\mathrm{d}}$ & 0.062 & $0.89-1.13$ & $<0.0001$ \\
\hline 143 to $250 \mathrm{~d}$ & $0.53^{\mathrm{b}}$ & 0.099 & $0.33-0.72$ & $<0.0001$ \\
\hline \multicolumn{5}{|c|}{ Relative test-day milk yield, ${ }^{3} \mathrm{~kg}$ (third test-day) } \\
\hline 0 to $30 \mathrm{~d}$ & $0.21^{\mathrm{a}}$ & 0.097 & $0.02-0.40$ & 0.02 \\
\hline 31 to $52 \mathrm{~d}$ & $0.89^{\mathrm{c}}$ & 0.055 & $0.78-1.01$ & $<0.001$ \\
\hline 53 to $76 \mathrm{~d}$ & $1.14^{\mathrm{d}}$ & 0.046 & $1.04-1.23$ & $<0.001$ \\
\hline 77 to $142 \mathrm{~d}$ & $1.21^{\mathrm{d}}$ & 0.058 & $1.09-1.32$ & $<0.001$ \\
\hline 143 to $250 \mathrm{~d}$ & $0.68^{\mathrm{b}}$ & 0.094 & $0.49-0.86$ & $<0.001$ \\
\hline \multicolumn{5}{|c|}{ Cow 305 -d milk yield ${ }^{4} \mathrm{~kg}$} \\
\hline 0 to $30 \mathrm{~d}$ & $6,960^{\mathrm{a}}$ & 117 & $6,730-7,190$ & $<0.0001$ \\
\hline 31 to $52 \mathrm{~d}$ & $7,224^{\mathrm{c}}$ & 116 & $6,995-7,452$ & $<0.0001$ \\
\hline 53 to $76 \mathrm{~d}$ & $7,291^{\mathrm{d}}$ & 116 & $7,062-7,519$ & $<0.0001$ \\
\hline 77 to $142 \mathrm{~d}$ & $7,234^{\mathrm{c}}$ & 116 & $7,005-7,462$ & $<0.0001$ \\
\hline 143 to $250 \mathrm{~d}$ & $7,169^{\mathrm{b}}$ & 117 & $6,939-7,399$ & $<0.0001$ \\
\hline
\end{tabular}

${ }^{\mathrm{a}-\mathrm{e}}$ Values within a column bearing different superscripts letters differ $(P \leq 0.05)$.

${ }^{1}$ Significant covariates $(P \leq 0.05)$ in the final models included parity, relative cow and herd 305-d milk yield, calving season-year, and herd size. Herd was included as random effect in the analysis.

${ }^{2}$ Least squares means $P$-value.

${ }^{3}$ Values are deviations from the corresponding test-day milk yield average from cows calving in the same herd year-season.

${ }^{4}$ Absolute values.

for lower SCC in reduced dry period (28-30 d) also has been reported (Gulay et al., 2003; Rastani et al., 2005). In contrast, other studies (Church et al., 2008; Watters et al., 2008) reported that short dry periods (30 to 34 d) did not have an effect on intramammary infections or milk SCC when compared with 45-, 55-, and 60-d dry periods. Similarly, no effect on SCC and cases of mastitis was found in these studies for shortened (34 d) versus traditional ( $55 \mathrm{~d}$ ) dry period.

Contrary to the present results, a detrimental effect on SCS was found in Jersey cows for dry periods of 30 d or less (Kuhn et al., 2007), where values of SCS increased 10 and $4.6 \%$ relative to the overall mean for dry periods $\leq 20 \mathrm{~d}$ and 21 to $30 \mathrm{~d}$, respectively. Similarly, short dry periods had a negative effect on SCS with a trend to lower SCS for longer dry periods (Kuhn et al., 2006a).

\section{Milk Yield}

The association of dry period length with relative testday milk yield was consistent and significant, suggesting a lower milk production in early lactation for cows with previous short dry periods (0 to $30 \mathrm{~d}$ ). After controlling for significant variables, the LSM of relative test-day milk yield were $-0.39,-0.18$, and $0.21 \mathrm{~kg}$ for a short dry period $(0$ to $30 \mathrm{~d})$ in the first, second, and third test day. The largest value for relative milk yield in the first and second test day was for intermediate length of dry period (53 to $76 \mathrm{~d}$ ) with LSM of 1.30 and $1.22 \mathrm{~kg}$. For the third test day, the largest value was for the dry period category of 77 to $142 \mathrm{~d}(1.21 \mathrm{~kg})$. Extended (143 to $250 \mathrm{~d}$ ) dry periods also had a detrimental association with early lactation milk yield compared with the reference period (Table 3). Likewise, the lowest 305-d milk yield was for cows with a short previous dry period $(\mathrm{LSM}=6,960 \mathrm{~kg})$, followed by cows with an extended previous dry period (LSM $=7,169 \mathrm{~kg})$. The largest 305d milk production was for the intermediate dry period category $(7,291 \mathrm{~kg}$, Table 3$)$.

Consistent with the current results, a previous study reported that cows dry less than $40 \mathrm{~d}$ produced less milk in the following lactation compared with cows with longer dry periods (Funk et al., 1987). Recent studies also reported reductions in milk, fat, and protein yields in the subsequent lactation in short $(\leq 30)$ dry periods (Kuhn et al., 2006a, 2007). A minimum dry period of 40 to $45 \mathrm{~d}$ maximized production across first and second 
Table 4. Least squares means for reproductive parameters for different categories of length of the dry period $^{1}$

\begin{tabular}{lcccc}
\hline Dry period category $^{2}$ & LSM & SEM & $95 \%$ CI & $P$-value $^{3}$ \\
\hline CFSI, d & & & & \\
0 to $30 \mathrm{~d}$ & $83.0^{\mathrm{a}}$ & 1.45 & $80.2-85.9$ & $<0.0001$ \\
31 to $52 \mathrm{~d}$ & $86.3^{\mathrm{b}}$ & 1.31 & $83.7-88.9$ & $<0.0001$ \\
53 to $76 \mathrm{~d}$ & $86.5^{\mathrm{b}}$ & 1.29 & $84.0-89.1$ & $<0.0001$ \\
77 to $142 \mathrm{~d}$ & $89.3^{\mathrm{c}}$ & 1.32 & $86.7-91.9$ & $<0.0001$ \\
143 to 250 d & $89.4^{\mathrm{c}}$ & 1.49 & $86.5-92.3$ & $<0.0001$ \\
CCI, d & & & & \\
0 to 30 d & $128.2^{\mathrm{a}}$ & 2.13 & $124.0-132.4$ & $<0.0001$ \\
31 to 52 d & $127.8^{\mathrm{a}}$ & 1.76 & $124.3-131.2$ & $<0.0001$ \\
53 to $76 \mathrm{~d}$ & $128.9^{\mathrm{a}}$ & 1.69 & $125.7-132.3$ & $<0.0001$ \\
77 to $142 \mathrm{~d}$ & $131.9^{\mathrm{b}}$ & 1.79 & $128.4-135.4$ & $<0.0001$ \\
143 to $250 \mathrm{~d}$ & $131.4^{\mathrm{ab}}$ & 2.26 & $127.0-135.9$ & $<0.0001$ \\
SC, services & & & & \\
0 to $30 \mathrm{~d}$ & $1.62^{\mathrm{b}}$ & 0.024 & $1.57-1.67$ & $<0.0001$ \\
31 to $52 \mathrm{~d}$ & $1.58^{\mathrm{a}}$ & 0.020 & $1.54-1.62$ & $<0.0001$ \\
53 to $76 \mathrm{~d}$ & $1.65^{\mathrm{c}}$ & 0.020 & $1.61-1.69$ & $<0.0001$ \\
77 to $142 \mathrm{~d}$ & $2.09^{\mathrm{d}}$ & 0.020 & $2.04-2.12$ & $<0.0001$ \\
143 to 250 d & $2.44^{\mathrm{e}}$ & 0.024 & $2.39-2.48$ & $<0.0001$ \\
\hline
\end{tabular}

${ }^{\mathrm{a} e}$ Values within a column bearing different superscripts letters differ $(P \leq 0.05)$.

${ }^{1}$ Significant covariates $(P \leq 0.05)$ in the final models included relative cow and herd $305-\mathrm{d}$ milk yield, calving season-year, and herd size. Herd was included as random effect in the analysis.

${ }^{2} \mathrm{CFSI}=$ calving-to-first-service interval, $\mathrm{CCI}=$ calving to conception interval, $\mathrm{SC}=$ services per conception

${ }^{3}$ Least squares means $P$-value.

lactations, and a dry period of at least 40 to $45 \mathrm{~d}$ was required to maximize production after second and third lactations (Kuhn et al., 2006). Rastani et al. (2005) indicated that milk yield from 1 to 70 DIM was greater in cows with 56- versus 28-d dry periods; however, when yields were corrected for total solids, no significant effect of dry period length was observed. Similarly, cows with traditional 55-d dry periods produced more milk than cows with shortened 34-d dry periods (Watters et al., 2008).

Omitting the dry period also resulted in lower milk yield during wk 1 to 12 postpartum (de Feu et al., 2009; Klusmeyer et al., 2009). A within-cow, half-udder model was used to compare the effect of quarter drying off within respective half udders at either 30 or $70 \mathrm{~d}$ on the ability of the half udders to subsequently produce milk. The 30 -d-dry half udders produced $18.9 \%$ less milk than the 70-d-dry half udders from d 3 to 100 of the subsequent lactation. Contrary to the present results, some studies indicated no significant differences in subsequent milk yield between shorter dry periods (30-35 d) compared with a conventional (42-60 d) dry period (Gulay et al., 2003; Pezeshki et al., 2007; Klusmeyer et al., 2009).

\section{Reproductive Parameters}

Dry period length had a significant association with the reproductive parameters. Least squares means for CFSI, CCI, and SC by dry period length categories are presented in Table 4 . Longer dry periods were associated with increased number of days for CFSI and CCI. Values for CFSI were $83 \mathrm{~d}$ and $89.4 \mathrm{~d}$ for short $(0$ to $30 \mathrm{~d})$ and extended (143 to $250 \mathrm{~d}$ ) dry periods, respectively. Average CCI were $127.8 \mathrm{~d}$ and $131.9 \mathrm{~d}$ for dry period categories 31 to $52 \mathrm{~d}$ and 77 to $142 \mathrm{~d}$, respectively.

Likewise, the number of SC increased with length of previous dry period from 1.58 (31 to $52 \mathrm{~d}$ ) to 2.44 (143 to $250 \mathrm{~d}$ ). Intermediate length (days) of dry period increased the odds of conception at the first service (Table 5). The odds of conceiving at the first service for cows in the extended dry period category were 0.88 (OR; $95 \% \mathrm{CI}=0.81$ to 0.94$)$ times the odds of conceiving for cows in the reference category.

In previous studies, cows with no planned dry period compared with cows with a standard ( 8 wk) dry period had higher first-service conception rate, fewer SC, and fewer days open (Gümen et al., 2005; Grummer, 2007). Further, first ovulation after calving occurred earlier in the group of cows with no planned dry period (Gümen et al., 2005) and anovular cows by 70 DIM in a shortened dry period were half of the anovular cows in a traditional dry period (Watters et al., 2009).

Kuhn et al. (2006a, 2007) reported fewer days open during the subsequent lactation for shorter dry periods. However, when models were adjusted for milk yield, shorter dry periods resulted in poorer subsequent fertility. In another study, the first postpartum ovulation occurred earlier for cows with no planned dry period 
compared with cows with a standard (8 wk) dry period (16.9 vs. 24.8 d postpartum). However, dry period duration did not affect calving to service interval, conception rate at first service, calving to conception interval, or overall pregnancy rate (de Feu et al., 2009).

Results from the Cox proportional hazard model indicated that, after controlling for parity, year and season of calving, herd size, and cow and herd milk yield, cows with short dry period were at the highest risk of receiving a first breeding (hazard ratio, $\mathbf{H R}=$ 1.02). A similar trend was observed in the Kaplan-Meier survival curves for the interval from calving to first service for the different categories of length of the dry period (Figure 1). Similarly, the hazard for pregnancy decreased by 4 and $6 \%$ for dry period categories 77 to $142 \mathrm{~d}$ and 143 to $250 \mathrm{~d}$, respectively, when compared with the reference dry period category (53 to 76 d; Table 7 and Figure 1). The effect of cow-relative 305-d milk yield on the hazard for pregnancy was significant. The hazard was greatest for the low milk yield category $(\mathrm{HR}=1.56)$ followed by the intermediate level (HR $=1.20)$. Unexpectedly, the hazard for pregnancy was lower for second-parity cows compared with cows in fourth or higher parity $(\mathrm{HR}=0.93)$.

\section{Culling}

Differences in length of dry period were significantly associated with the level of live culling. After controlling for parity, year and season of calving, herd size, and cow and herd milk yield, cows with previous short $(0$ to $30 \mathrm{~d})$ dry periods had the highest odds of live culling when compared with cows in the reference (53 to $76 \mathrm{~d})$ group ( $\mathrm{OR}=2.20 ; 95 \%$ CI 1.93 to 2.51$)$. Cows with extended (143 to $250 \mathrm{~d}$ ) dry period had the second highest odds of live culling compared with the reference group (OR $=1.57 ; 95 \%$ CI 1.37 to 1.80 ; Table 6$)$.

When compared with the reference group (53 to 76 d), cows in the dry period category 77 to $142 \mathrm{~d}$ had the highest odds of death $(\mathrm{OR}=1.27 ; 95 \%$ CI 1.15 to 1.40$)$ followed by the category 143 to $250 \mathrm{~d}(\mathrm{OR}=1.18 ; 95 \%$ CI 1.02 to 1.38; Table 6). However, when death and live culling were combined, the highest odds were for cows in the categories 0 to $30 \mathrm{~d}(\mathrm{OR}=1.63 ; 95 \%$ CI 1.46 to 1.82$)$ and 143 to $250 \mathrm{~d}(\mathrm{OR}=1.44 ; 95 \%$ CI 1.29 to 1.61; Table 6).

The time-to-event analyses indicated that the risk of culling (death and live culling) before 100 DIM was higher for cows in the category 77 to $142 \mathrm{~d}$ ( $\mathrm{HR}=$ $1.17 ; P \leq 0.0001)$ followed by the extended dry period category (143 to $250 \mathrm{~d} \mathrm{HR}=1.15, P \leq 0.002$; Table 7 ). There was inconsistency between the logistic regression and the Cox's hazard regression model for the outcomes in overall culling in the categories 0 to $30 \mathrm{~d}$ and 31
Table 5. Odds ratios for conception at first service by categories of length of the dry period (reference dry period $=56$ to $76 \mathrm{~d})^{1}$

\begin{tabular}{llccc}
\hline $\begin{array}{l}\text { Dry period } \\
\text { category }\end{array}$ & $\begin{array}{c}\%(\mathrm{n}) \\
\text { affected }\end{array}$ & $\begin{array}{c}\text { Odds } \\
\text { ratio }\end{array}$ & $\begin{array}{c}95 \% \\
\mathrm{CI}^{2}\end{array}$ & $P$-value \\
\hline 0 to $30 \mathrm{~d}$ & $41(1,658)$ & 0.93 & $0.90-1.00$ & 0.06 \\
31 to $52 \mathrm{~d}$ & $42(6,924)$ & 1.00 & $1.00-1.04$ & 0.79 \\
53 to $76 \mathrm{~d}$ & $42(15,493)$ & 1 & - & - \\
77 to $142 \mathrm{~d}$ & $40(5,399)$ & 0.92 & $0.89-0.96$ & $<0.0001$ \\
143 to 250 d & $38(1,263)$ & 0.88 & $0.81-0.94$ & 0.0003 \\
\hline
\end{tabular}

${ }^{1}$ Significant covariates $(P \leq 0.05)$ in the final model included parity, relative cow, calving season-year, and herd size. Herd was included as random effect in the analysis.

${ }^{2} 95 \%$ CI for the odds ratio.

to $52 \mathrm{~d}$ (Table 6). However, in both cases, one of the contrasting estimations had a large $P$-value, indicating a lack of statistical significance.

As expected, the risk of culling was greater for cows in their fourth or higher parity and for low-producing cows (Table 7). Similarly, cows in large and low-producing herds were at greater risk of culling. One limitation in the present study is that the analysis was based on the association of dry period length with subsequent lactation; therefore, the information about cows that were culled or died prior to calving is missing. It may be assumed that the inclusion of these cases had made the detrimental effect of extreme categories of dry period more remarkable.

Overall, the negative effect of unconventional dry period lengths was more severe for extended dry periods. This extension was, in most of the cases, involuntary. Delays in the time to conception, with the resulting decrease in milk yield at the end of lactation, or errors in the breeding records may result in a premature drying off. These cows may have an increased risk of overconditioning toward the end of their lactation (Morrow, 1976; Cole et al., 2009), and consequently could be under increased risk of reduced performance, health problems, death, or culling after the subsequent calving because of related metabolic problems (Chassagne et al., 1999; Heuer et al., 1999).

A negative effect of a short dry period was only associated with milk yield and culling. As with extended categories, it is expected that in this population, most of these cows had involuntary shortened dry periods, mainly due to incorrect recording of breeding dates or management oversight, and consequently, these cows missed the opportunity of an adequate transition from both a nutritional and a metabolic point of view.

Contrary to most of the previous studies that followed a more controlled design (Gümen et al., 2005; Rastani et al., 2005; Watters et al., 2008, 2009), the current report analyzed retrospective data, and required statistical analysis to control for potential confounding 

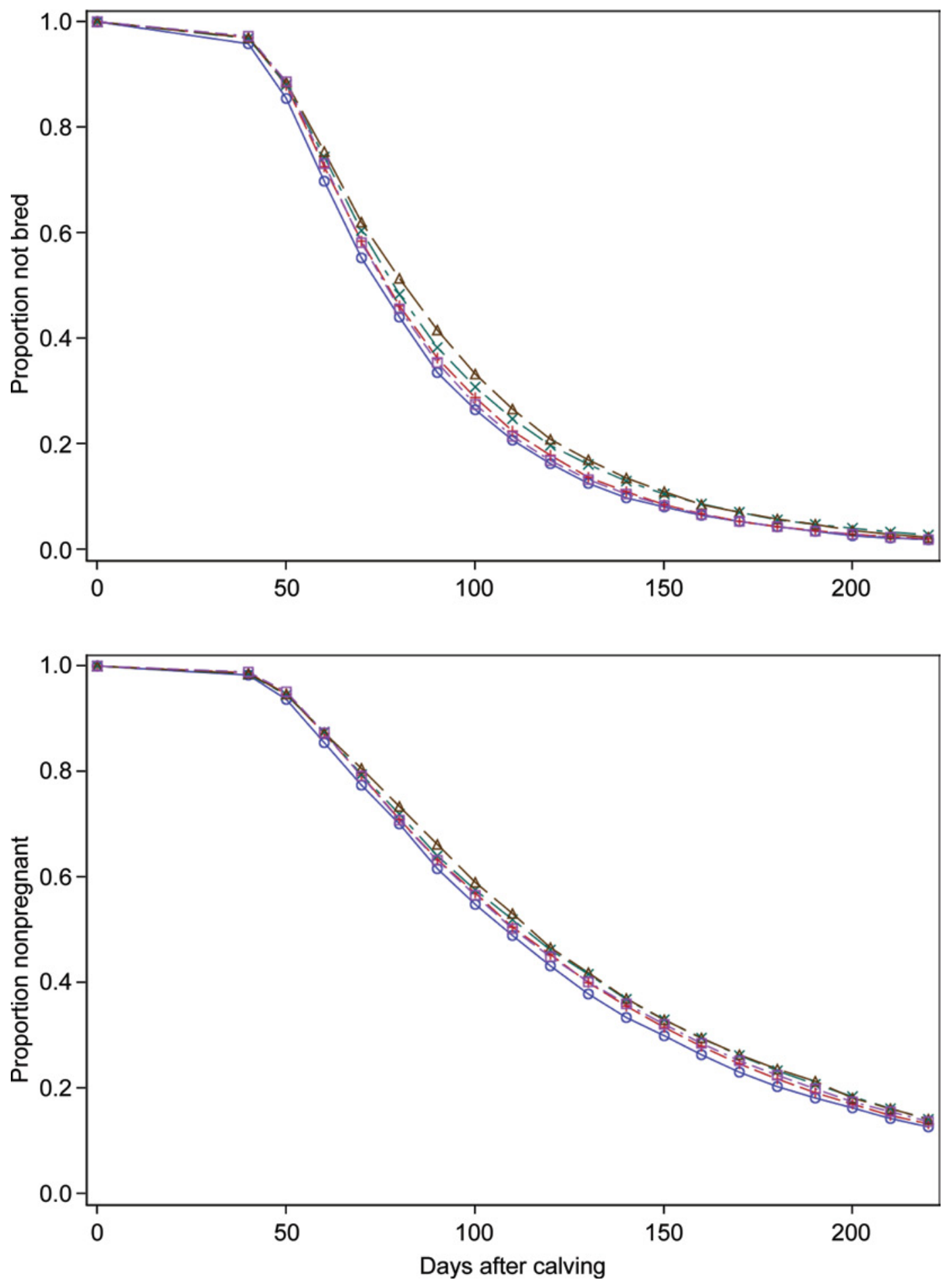

Figure 1. Kaplan-Meier survival curves for the (top) interval from calving to first service and (bottom) the proportion of nonpregnant cows by days after calving by different categories of length of the dry period. Median intervals from calving to first service for dry period length categories 0 to $30 \mathrm{~d}, 31$ to $52 \mathrm{~d}, 53$ to $76 \mathrm{~d}, 77$ to $142 \mathrm{~d}$, and 143 to $250 \mathrm{~d}$ were $74,76,76,78$, and $80 \mathrm{~d}$. Median intervals from calving to pregnancy for the same categories were 109, 110, 110, 113, and $114.5 \mathrm{~d}$. Dry period length categories: 0 to $30 \mathrm{~d}(\mathrm{o}) ; 31$ to $52 \mathrm{~d}(+) ; 53$ to $76 \mathrm{~d}(\square) ; 77$ to $142 \mathrm{~d}(\times)$; and 143 to $250 \mathrm{~d}(\Delta)$. Color version available in the online PDF. 
PINEDO ET AL.

Table 6. Odds ratios for occurrence of death, live culling, and overall culling up to 100 DIM by categories of length of the dry period (reference dry period $=56$ to $76 \mathrm{~d})^{1}$

\begin{tabular}{lcccc}
\hline $\begin{array}{l}\text { Dry period } \\
\text { category }\end{array}$ & $\begin{array}{c}\%(\mathrm{n}) \\
\text { affected }\end{array}$ & $\begin{array}{c}\text { Odds } \\
\text { ratio }\end{array}$ & $\begin{array}{c}95 \% \\
\text { CI }^{2}\end{array}$ & $P$-value \\
\hline $\begin{array}{l}\text { Live culling } \\
0 \text { to } 30 \mathrm{~d}\end{array}$ & $7.5(388)$ & 2.20 & $1.92-2.51$ & $<0.0001$ \\
31 to $52 \mathrm{~d}$ & $4.0(786)$ & 1.02 & $0.92-1.13$ & 0.24 \\
53 to $76 \mathrm{~d}$ & $4.0(1,727)$ & 1 & - & - \\
77 to $142 \mathrm{~d}$ & $6.3(1,104)$ & 1.33 & $1.21-1.45$ & 0.0001 \\
143 to $250 \mathrm{~d}$ & $7.9(366)$ & 1.57 & $1.39-1.8$ & 0.0001 \\
Death & $3.1(158)$ & 0.93 & $0.81-1.13$ & 0.14 \\
0 to $30 \mathrm{~d}$ & $3.3(650)$ & 0.98 & $0.90-1.1$ & 0.83 \\
31 to $52 \mathrm{~d}$ & $2.9(1,267)$ & 1 & - & - \\
53 to $76 \mathrm{~d}$ & $4.6(800)$ & 1.27 & $1.20-1.4$ & $<0.001$ \\
77 to $142 \mathrm{~d}$ & $5.0(231)$ & 1.18 & $1.00-1.38$ & 0.04 \\
143 to $250 \mathrm{~d}$ & & & & \\
Culling $(\mathrm{death}$ and live culling) & $10.6(546)$ & 1.63 & $1.45-1.82$ & $<0.0001$ \\
0 to $30 \mathrm{~d}$ & $7.4(1,436)$ & 1.01 & $0.93-1.09$ & 0.29 \\
31 to $52 \mathrm{~d}$ & $4.0(2,994)$ & 1 & - & - \\
53 to $76 \mathrm{~d}$ & $10.9(1,904)$ & 1.33 & $1.25-1.43$ & $<0.0001$ \\
77 to $142 \mathrm{~d}$ & $12.9(597)$ & 1.44 & $1.29-1.61$ & $<0.0001$ \\
143 to $250 \mathrm{~d}$ & & & & \\
\hline
\end{tabular}

${ }^{1}$ Significant covariates $(P \leq 0.05)$ in the final models included parity, relative cow and herd 305-d milk yield, and calving season-year. Herd was included as random effect in the analysis.

${ }^{2} 95 \%$ CI for the odds ratio.

Table 7. Multivariable model for hazard ratio for pregnancy and overall culling (death and live culling) up to $100 \mathrm{DIM}^{1}$

\begin{tabular}{|c|c|c|c|c|}
\hline \multirow[b]{2}{*}{ Variable } & \multicolumn{2}{|c|}{ Pregnancy } & \multicolumn{2}{|c|}{ Culling } \\
\hline & Hazard ratio & $P$-value & Hazard ratio & $P$-value \\
\hline \multicolumn{5}{|l|}{ Dry period category } \\
\hline 0 to $30 \mathrm{~d}$ & 0.97 & 0.109 & 0.93 & 0.127 \\
\hline 31 to $52 \mathrm{~d}$ & 1.01 & 0.350 & 0.93 & 0.028 \\
\hline 53 to $76 \mathrm{~d}$ & 1.00 & - & 1.00 & - \\
\hline 77 to $142 \mathrm{~d}$ & 0.96 & 0.001 & 1.17 & $<0.0001$ \\
\hline 143 to $250 \mathrm{~d}$ & 0.94 & 0.003 & 1.15 & 0.002 \\
\hline \multicolumn{5}{|l|}{ Parity } \\
\hline 2 & 0.93 & $<0.0001$ & 0.46 & $<0.0001$ \\
\hline 3 & 1.00 & 0.916 & 0.82 & $<0.0001$ \\
\hline$\geq 4$ & 1.00 & - & 1.00 & - \\
\hline \multicolumn{5}{|c|}{ Cow relative $305-\mathrm{d}$ milk yield } \\
\hline$<-817 \mathrm{~kg}$ & 1.56 & $<0.0001$ & 1.56 & $<0.0001$ \\
\hline-817 to $786 \mathrm{~kg}$ & 1.20 & $<0.0001$ & 1.10 & 0.940 \\
\hline$>786 \mathrm{~kg}$ & 1.00 & - & 1.00 & - \\
\hline \multicolumn{5}{|c|}{ Herd relative 305 -d milk yield } \\
\hline$<-1,308 \mathrm{~kg}$ & 1.08 & $<0.0001$ & 1.45 & $<0.0001$ \\
\hline$-1,308$ to $1,744 \mathrm{~kg}$ & 0.98 & 0.013 & 1.30 & $<0.0001$ \\
\hline$>1,744 \mathrm{~kg}$ & 1.00 & - & 1.00 & - \\
\hline \multicolumn{5}{|c|}{ Herd size category (cows) } \\
\hline$<115$ & 1.05 & $<0.0001$ & 0.86 & $<0.0001$ \\
\hline 115 to 301 & 1.02 & 0.0524 & 0.92 & 0.0025 \\
\hline$>301$ & 1.00 & - & 1.00 & - \\
\hline \multicolumn{5}{|l|}{ Calving season } \\
\hline Summer & 1.03 & 0.018 & 0.87 & $<0.0001$ \\
\hline Fall & 1.04 & 0.001 & 0.90 & 0.002 \\
\hline Winter & 1.01 & 0.231 & 1.05 & 0.122 \\
\hline Spring & 1.00 & - & 1.00 & - \\
\hline
\end{tabular}

${ }^{1}$ Significant covariates $(P \leq 0.05)$ in the final model included parity, relative cow and herd 305-d milk yield, calving season-year, and herd size. 
variables. Overall, extreme categories of number of days dry $(0$ to $30 \mathrm{~d}$ and 143 to $250 \mathrm{~d}$ ) had the most severe impact on the outcomes measured in this population. However, in contrast with balanced randomized studies where individuals are allocated to the different treatments, these 2 categories accounted for only $10 \%$ of the records analyzed.

Although some of the farms in this analysis may have purposely chosen longer or shorter dry periods, it is expected that, in most of the cases, the deviations from the conventional $60-\mathrm{d}$ dry period were involuntary. The differences in dry period length observed in this retrospective study may be related poor reproductive management and record keeping, which may have resulted in a confounding effect. Consequently, it is expected that a potential association between level of management and higher frequencies of extreme length of dry periods existed in this population. However, the large data set and the inclusion of herd milk yield and herd (random effect) in the models accounted for differences in management among the study herds.

\section{CONCLUSIONS}

Length of dry period was associated with udder health, culling, and overall performance during early lactation. Extended dry periods (143 to $250 \mathrm{~d}$ ) were associated with increased odds of subclinical mastitis during early lactation and had a negative effect on reproductive performance. Short (0 to $30 \mathrm{~d}$ ) and extended dry periods had a detrimental effect on early lactation and 305-d milk yield and increased the risk of overall culling when compared with the reference dry period (53 to $76 \mathrm{~d})$.

\section{ACKNOWLEDGMENTS}

The authors thank Insecabio Ltda. (Los Angeles, Chile) for graciously providing the database analyzed in the present study.

\section{REFERENCES}

Annen, E. L., R. J. Collier, M. A. McGuire, and J. L. Vicini. 2004. Effects of dry period length on milk yield and mammary epithelial cells. J. Dairy Sci. 87:E66-E76.

Bachman, K. C., and M. L. Schairer. 2003. Invited review: Bovine studies on optimal lengths of dry periods. J. Dairy Sci. 86:30273037.

Chassagne, M., J. Barnouin, and J. P. Chacornac. 1999. Risk factors for stillbirth in Holstein heifers under field conditions in France: A prospective survey. Theriogenology 51:1477-1488.

Church, G. T., L. K. Fox, C. T. Gaskins, D. D. Hancock, and J. M. Gay. 2008. The effect of a shortened dry period on intramammary infections during the subsequent lactation. J. Dairy Sci. 91:4219-4225.

Cole, J. B., D. J. Null, and P. M. VanRaden. 2009. Best prediction of yields for long lactations. J. Dairy Sci. 92:1796-1810.

de Feu, M. A., A. C. O. Evans, P. Lonergan, and S. T. Butler. 2009. The effect of dry period duration and dietary energy density on milk production, bioenergetic status, and postpartum ovarian function in Holstein-Friesian dairy cows. J. Dairy Sci. 92:6011-6022.

Eberhart, R. J. 1986. Management of dry cows to reduce mastitis. J. Dairy Sci. 69:1721-1732.

Funk, D. A., A. E. Freeman, and P. J. Berger. 1987. Effects of previous days open, previous days dry, and present days open on lactation yield. J. Dairy Sci. 70:2366-2373.

Grummer, R. R. 2007. Strategies to improve fertility of high yielding dairy farms: Management of the dry period. Theriogenology 68S:S281-S288.

Grummer, R. R., and R. R. Rastani. 2004. Why reevaluate dry period length? J. Dairy Sci. 87(E. Suppl.):E77-E85.

Gulay, M. S., M. J. Hayen, K. C. Bachman, T. Belloso, M. Liboni, and H. H. Head. 2003. Milk production and feed intake of Holstein cows given short (30-d) or normal (60-d) dry periods. J. Dairy Sci. 86:2030-2038.

Gümen, A., R. R. Rastani, R. R. Grummer, and M. C. Wiltbank. 2005. Reduced dry periods and varying prepartum diets alter postpartum ovulation and reproductive measures. J. Dairy Sci. 88:2401-2411.

Heuer, C., Y. H. Schukken, and P. Dobbelaar. 1999. Postpartum body condition score and results from the first test day milk as predictors of disease, fertility, yield, and culling in commercial dairy herds. J. Dairy Sci. 82:295-304.

Hurley, W. L. 1989. Mammary gland function during involution. J. Dairy Sci. 72:1637-1646.

Instituto Geografico Militar. 2006. Mapas de Chile. http://www.igm. cl Accessed Nov. 15, 2009.

Keown, J. F., R. W. Everett, N. B. Empet, and L. H. Wadell. 1986. Lactation curves. J. Dairy Sci. 69:769-781.

Klusmeyer, T. H., A. C. Fitzgerald, A. C. Fabellar, J. M. Ballam, R. A. Cady, and J. L. Vicini. 2009. Effect of recombinant bovine somatotropin and a shortened or no dry period on the performance of lactating dairy cows. J. Dairy Sci. 92:5503-5511.

Kuhn, M. T., J. L. Hutchison, and H. D. Norman. 2006. Dry period length to maximize production across adjacent lactations and lifetime production. J. Dairy Sci. 89:1713-1722.

Kuhn, M. T., J. L. Hutchison, and H. D. Norman. 2006a. Effects of length of dry period on yields of milk fat and protein, fertility and milk somatic cell score in the subsequent lactation of dairy cows. J. Dairy Res. 73:154-162.

Kuhn, M. T., J. L. Hutchison, and H. D. Norman. 2007. Dry period length in US Jerseys: Characterization and effects on performance. J. Dairy Sci. 90:2069-2081.

Moore, D. A., M. W. Overton, R. C. Chebel, M. L. Truscott, and H. BonDurant. 2005. Evaluation of factors that affect embryonic loss in dairy cattle. J. Am. Vet. Med. Assoc. 226:1112-1118.

Morrow, D. A. 1976. Fat cow syndrome. J. Dairy Sci. 59:1625-1629.

Natzke, R. P., R. W. Everett, and D. R. Bray. 1975. Effect of drying off practices on mastitis infection. J. Dairy Sci. 58:1828-1835.

NRC. 2001. Nutrient Requirements of Dairy Cattle. 7th rev. ed. Natl. Acad. Sci. Washington, DC.

Pezeshki, A., J. Mehrzad, G. R. Ghorbani, H. R. Rahmani, R. J. Collier, and C. Burvenich. 2007. Effects of short dry periods on performance and metabolic status in Holstein dairy cows. J. Dairy Sci. 90:5531-5541.

Rastani, R. R., R. R. Grummer, S. J. Bertics, A. Gümen, M. C. Wiltbank, D. G. Mashek, and M. C. Schwab. 2005. Reducing dry period length to simplify feeding transition cows: Milk production, energy balance, and metabolic profiles. J. Dairy Sci. 88:1004-1014.

Swanson, E. W. 1965. Comparing continuous milking with sixty-day dry periods in successive lactations. J. Dairy Sci. 48:1205-1209.

Watters, R. D., J. N. Guenther, A. E. Brickner, R. R. Rastani, P. M. Crump, P. W. Clark, and R. R. Grummer. 2008. Effects of dry period length on milk production and health of dairy cattle. J. Dairy Sci. 91:2595-2603.

Watters, R. D., M. C. Wiltbank, J. N. Guenther, A. E. Brickner, R. R. Rastani, P. M. Fricke, and R. R. Grummer. 2009. Effect of dry period length on reproduction during the subsequent lactation. J. Dairy Sci. 92:3081-3090. 